\title{
The Effect of Mathematical Connections on the Mastery of Probability Material
}

\author{
Fauzan Sulman 1, a), Muhammad Reyza Arif Taqwa², Aminah Zb ${ }^{1}, \operatorname{Rafzan}^{3}$, \\ Ahmad Fikri ${ }^{4}$
}

${ }^{1}$ Universitas Islam Negeri Sulthan Thaha Saifuddin Jambi Jambi-Muaro Bulian Street, Muaro Jambi, Jambi, Indonesia, 36361

${ }^{2}$ Universitas Negeri Malang

5 Semarang Street, Sumbersari, Lowokwaru, Kota Malang, Jawa Timur, Indonesia, 65145

${ }^{3}$ Universitas Negeri Jambi

Jambi-Muara Bulian Street Km. 15, Mendalo Darat, Jaluko, Jambi, Indonesia, 36122

${ }^{4}$ Agama Islam Negeri Kerinci

Muradi Street, Sungai Liuk, Pesisir Bukit, Sungai Penuh, Jambi, Indonesia, 37152

a)fauzansulman@uinjambi.ac.id

\begin{abstract}
Abstrak. This study aims to analyze students' mathematical connections in terms of their initial ability to material opportunities. This type of research uses a quantitative approach with a quasi-experimental method with the design of this research is the Two Group Pretest-posttest. The population of this study was all students of semester VI Physics Tadris UIN Sulthan Thaha Saifuddin Jambi, totaling 42 people. The sampling technique used was saturated sampling with research instruments in the form of test descriptions. Data were analyzed using a paired t-test test. From the calculation results, the value $-\mathrm{t}_{\text {table }} \leq \mathrm{t}_{\text {count }} \leq+\mathrm{t}_{\text {table }}$ is $-2.02 \leq 7.84 \geq+2.02$, then $\mathrm{H} 0$ is rejected and Ha is accepted at the significance level $\alpha=0.05$. So it can be stated that there are differences in student learning outcomes with high initial mathematical abilities compared to low initial mathematical abilities. The results of the research correlation test (test phi $(\Phi)$ ), where the calculation results obtained $r_{\text {tabel }}$ value $\leq r_{\text {count }}$, namely $0.305 \leq 0.873$ then $\mathrm{H} 0$ is rejected and $\mathrm{Ha}$ is accepted at the significance level $\alpha=0.05$. So that it can be revealed that the initial mathematical ability has a significant effect on student learning outcomes on probability.
\end{abstract}

Keywords: Early Mathematical Ability, Learning Outcomes, Mathematical Connection, Probability.

\begin{abstract}
Abstrak. Penelitian ini bertujuan untuk menganalisis koneksi matematis mahasiswa dilihat dari kemampuan awal terhadap terhadap materi peluang. Jenis penelitian ini menggunakan pendekatan kuantitatif dengan metode quasi experimental dengan desain penelitian ini adalah the Two Group Pretest-posttest. Populasi penelitian ini adalah seluruh mahasiswa semester VI Tadris Fisika UIN Sulthan Thaha Saifuddin Jambi yang berjumlah 42 Orang. Teknik sampling yang digunakan adalah sampling jenuh dengan Instrumen penelitian berupa tes uraian. Data dianalisis dengan menggunakan uji $\mathrm{t}_{\text {test. }}$. Dari hasil perhitungan diperoleh nilai $-\mathrm{t}_{\text {tabel }} \leq \mathrm{t}_{\text {hitung }} \leq+\mathrm{t}_{\text {tabel }}$ yaitu $-2,02 \leq$ $7,84 \geq+2,02$, maka $\mathrm{H}_{0}$ ditolak dan $\mathrm{H}_{\mathrm{a}}$ diterima pada taraf signifikansi $\alpha=0,05$. Sehingga dapat dinyatakan bahwa terdapat perbedaan hasil belajar mahasiswa kemampuan awal matematik tinggi dibanding dengan keamampuan awal matematik rendah. Hasil penelitian dilanjutkan uji koreslasi (Uji phi $(\Phi)$ ), dimana dari hasil perhitungan diperoleh nilai $r_{\text {tabel }} \leq r_{\text {hitung }}$ yaitu $0,305 \leq 0,873$ maka $\mathrm{H}_{0}$ ditolak dan $\mathrm{H}_{\mathrm{a}}$ diterima pada taraf signifikansi $\alpha=0,05$. Sehingga dapat disimpulkan bahwa kemampuan awal matematik memberikan pengaruh yang signifikan terhadap hasi belajar mahasiswa pada materi probabilitas.
\end{abstract}

Kata kunci: Hasil Belajar, Kemampuan Awal Matematik, Koneksi Matematis, Materi Peluang 


\section{INTRODUCTION}

Education is an effort to improve the quality of human resources both in terms of creativity and productivity. It is an undeniable reality that a creative and productive teacher is very influential in global competition (Gucyeter \& Erdogan, 2020; Hadar \& Tirosh, 2019), education will be the basic foundation (Nasri, Yusof, Ramasamy, \& Halim, 2010) In shaping the character of students, therefore in education in the industrial era 5.0, it is hoped that they will not be left far behind due to the very rapid development of technology and life in the present. (Astawa, 2016) A better analysis is needed on how to find a solution to a problem or situation so that by conditioning the learning into ideal learning (Fajri, 2017; Anggralia, Deswita, Erita, Habibi, \& Putra, 2019). The learning process must aim to prepare students for their profession in the future, in other words, learning must be at the forefront of making professional staff (Nasri et al., 2010). The shift of the educational paradigm today has an impact on how the ideal learning process in the lecture environment should be. The recovery process in higher education contains educational principles that are thought out ideally and effectively with criteria that have been prepared with the KKNI in realizing the goals of national education (Safi'i, 2017), provide understanding to each department or study program at higher education to realize a more effective and efficient lecture process.

The lecture process that occurs in the present is a catalyst (Burbules, Fan, \& Repp, 2020), put forward the aspects of student needs to meet the future, or the assignments they will undertake in the future both in terms of organization and analyzing the material to be taught. In the lecture process that is carried out, it must have a constructivist point of view so that lectures are closer, by developing creative thinking skills and this is the goal of national education (Wahyuni \& Kurniawan, 2018). In the lecture process, you must implement the development of a learning strategy that can develop aspects and development of students in the lecture process, one of which is the development of higher-order thinking skills (higher-order thinking skills). (Widodo \& Kadarwati, 2013) especially on material that uses a lot of mathematical calculations, one of which is probability material so that students' initial mathematical abilities are needed in lectures, this understanding is based on NCTM and in elementary and middle school mathematics about mathematical connections (Mathematical Connection) is used as a standard (Maulida, Suyitno, \& Asih, 2019) so that it is interested to see its small part, namely the initial mathematical ability, in line with this (Kusmanto \& Marliyana, 2014) Mathematical connection is the relationship between mathematics and several concepts of scientific disciplines so that students can solve mathematical problems. (Hardiyati, 2014), In other words, there are initial skills needed by students in completing learning, one of which is the initial mathematical abilities and these problems are found in many physics materials, where many physics studies require these initial mathematical abilities and learning difficulties usually result in misconceptions of students (Taqwa, Shodiqin, \& Zainuddin, 2020). 
Most of the probability lectures use mathematical principles using differential or integral or simple mathematics so that students must have good mathematical skills (Yotongyos, Traiwichitkhun, \& Kaemkate, 2015). Most of the probability lectures use mathematical principles using differential or integral or simple mathematics so that students must have good mathematical skills (Marsitin \& Sesanti, 2019). In line with that (Amalia, 2017) a strong understanding of concepts and the combination of the right concepts and a strong mathematical understanding will make student understanding in analyzing the material presented will be better, understanding integral and differential understanding plays a very important role in the analysis of some formulas in physics, student mathematical connections will lead to student understanding can not run optimally (Amalia, 2017; Marsitin \& Sesanti, 2019).

Based on the understanding of a mathematical connection NCTM (2000) summarizes the mathematical connection indicator in three major components, (Hendriana, Rohaeti, \& Sumarmo, 2017). The components namely: (1) Looking deeper into mathematical ideas and examples; (2) Forming a comprehensive link between old mathematical ideas and new ideas; (3) Analyze and apply a mathematical content or topic outside of mathematics. This shows the importance of the strong role of mathematics in probability, and here the researcher takes the second point, namely forming a comprehensive linkage between old mathematical ideas and new ideas, in other words, it is called the initial mathematical ability.

The probability of the material having a very large relationship with the ability of mathematical connections where the connection of mathematical concepts that students have will make it easier for them to analyze (Fajri, 2017; Nuriana \& Yaya, 2014) This probability equation is in line with research where students who can solve mathematical problems have good analytical skills so that they can solve problems properly and accurately. The students' mastery of mathematics only needs to assess the correct understanding of the concept on this probability, without having to learn basic mathematical principles, with understanding the correct concepts and good mathematics, it will create easier mastery of knowledge. The explanation above makes researchers interested and has carried out an analysis of the effect of students' mathematical connections on learning outcomes in the probability material.

\section{METHOD}

Researchers used a quantitative approach with the Quasi-experimental method with the design in this study was the Two Groups Pretest-posttest, where this design was used to compare the results of the pretest and posttest in the two groups conducted research, The design of the study can be seen in Figure 1. 


\section{$\mathbf{O} \times \mathbf{O}$ \\ $\mathbf{O} \times \mathbf{O}$}

Figure 1. Two Group Pretest-Posttest Research Design

The treatment was carried out in two class groups, both the experimental group (O1) and the control group $(\mathrm{O} 2)$, the difference was only in the pre-test average value of the students' initial mathematical conclusions. The research steps can be seen in Figure 2.

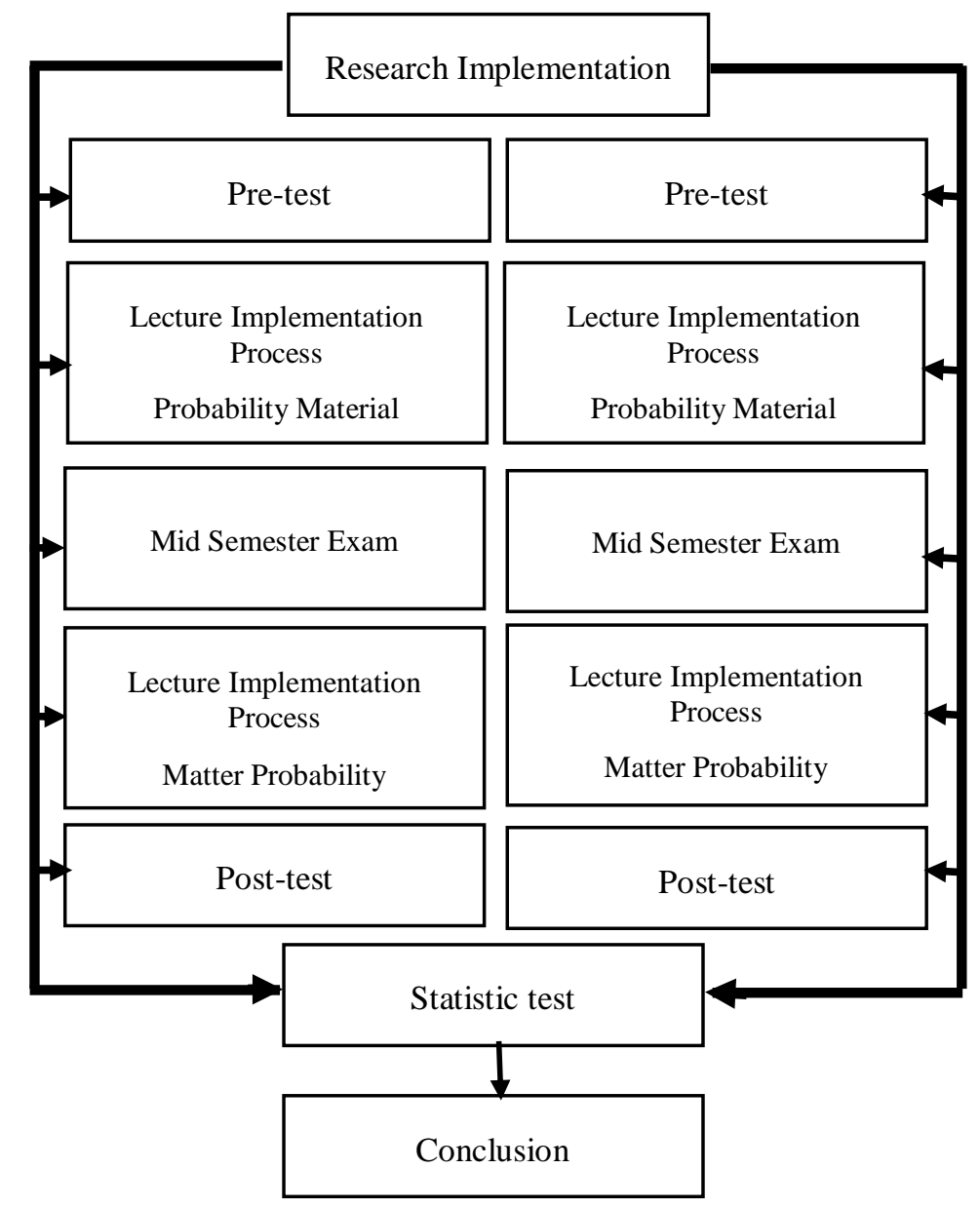

Figure 2. Chart of Research Implementation

The subjects of this study were students of UIN Sulthan Thaha Saifuddin in odd semesters, to be precise in the fifth semester which consisted of two classes. The sampling technique in this study is to use saturated samples where all population is the subject of the study (Sugiyono, 2014). The students involved in this study were 42 students, the withdrawal of the experimental class and the control was based on the results of the students' initial mathematics communication tests where the students were. 
The instruments used in this study consist of three types, namely the initial test (pre-test) of the initial mathematical connection, the Lesson Plans (RPS), and the final test instrument (post-test) of the student learning results in the probability material. The instrument developed is validated in advance, the instrument is good for the plan of conducting the initial mathematical ability test of the study results and the final test of the student's study results will be analyzed using the logical validity and validity of the content. For logical validity instruments by asking for expert information involving three peoples with details of one linguist, one mathematician, and one more expert on probability materials. In addition to using logical validity, especially for the initial mathematical connection and the final test of learning outcomes, an instrument calibration analysis is also carried out with the eligibility criteria. Namely, the question must be valid, have good distinction and difficulty level, and have high reliability, so that the resulting instrument is truly accurate in measuring the effect of students' initial mathematical connections on learning outcomes.

The technique used in the analysis was the t-test and continued with the phi-test. This is because the t-test can take the effect of the influence of the two existing variables whether there is a difference or not, and the t-test can also be used to see the effect of the comparison of learning outcomes. After the t-test analysis, the analysis of the trials was carried out to see how significant the influence was, according to the opinion, that the analysis can be seen phi can be used because the randomly observed variables between the experimental group and the control group have a striking difference. Data analysis was carried out after carrying out the prerequisite test, namely the normality and homogeneity test where the homogeneity test used the chi-square $\mathrm{X}^{2}$ technique. To see whether it is normal or not, then the homogeneity test uses the F test to see whether the variance is homogeneous or not between the second variable. To know that the data is normally distributed and homogeneous, after the prerequisite test analysis is used it turns out to be normal and homogeneous, then look at the t-test and the phi display. To see the effect of the initial ability of mathematical connections on student learning outcomes so that it can be seen how the differences and their significance affect student learning outcomes in the probability material.

\section{RESULTS AND DISCUSSION}

The data on the results of the assessment findings are obtained from the analysis of the initial test (pre-test), namely the test of students' mathematical abilities and the end with the final test (posttest) of student learning outcomes on probability science material with the type of question used is multiple choice, the value of student learning outcomes seen is student learning in the cognitive aspects both in the experimental class and in the control class on probability material, as shown in Table 1. 
Table 1. The score of Students' Initial Mathematics Learning Outcomes

\begin{tabular}{ccc}
\hline \multirow{2}{*}{ Parameter } & Experiment Class & Control Class \\
\cline { 2 - 3 } & Pre-test & Pre-test \\
\hline Lowest score & 67,18 & 67,82 \\
\hline Highest score & 87,50 & 90,12 \\
\hline Average score & 75,75 & 73,4 \\
\hline
\end{tabular}

Analysis of students learning outcomes scores on the final test on the cognitive aspects both in the experimental class and in the control class on the probability material, as shown in Table 2.

Table 2. Post-Test Scores on the Probability Material

\begin{tabular}{ccc}
\hline \multirow{2}{*}{ Parameter } & Experiment Class & Control Class \\
\cline { 2 - 3 } & Post-test & Post-test \\
\hline Lowest score & 78,70 & 72,30 \\
\hline Highest score & 98,20 & 91,78 \\
\hline Average score & 87,30 & 73,7 \\
\hline
\end{tabular}

Based on these data, it can be said that the average scores of the experimental class at the time of the test has a better mathematical score than the control class, both in terms of the highest and lowest scores, the experimental class still has a better score. from the control class. And these results are in line with the observations in the final test by giving probability questions and the results are under the previous researchers' suspicions that there is a straight line that the learning outcomes of students with high mathematical abilities will also have high results compared to low mathematical abilities in statistical physics material, and also reviewed. From the average score of the experimental class students who have high average math ability will produce a better understanding of the material of probability.

The quantitative data found requires a prerequisite test to answer the proposed research hypothesis whether there is an effect of students' initial mathematical ability on student learning outcomes, the probability and how significant is the effect on student learning outcomes, to answer the above one must first perform prerequisite tests, so that the analysis is correct and accurate to use. The Prerequisite Test for both the normality test and the homogeneity test was carried out using the final test data (Semester Final Examination) of students on probability. The normality test in the experimental class with a value of $\alpha=0.05$ or $5 \%$, the results obtained $X_{\text {count }}^{2} \leq X^{2}$ table, $4.564 \leq$ 12.5916 , the experimental class data is normally distributed while the control class $X^{2}$ count $\leq X^{2}$ table, $7.453 \leq 12.5916$ can be stated that the data is also normally distributed. Homogeneity Test for the experimental and control classes, namely using a significant level of $\alpha=5 \%$, the value of $\mathrm{X}^{2}$ table $=$ 2.71 and $\mathrm{X}_{\text {count }}^{2}=1.42$ was obtained. So $\mathrm{X}^{2}{ }_{\text {count }} \leq \mathrm{X}^{2}$ table can show homogeneous data variants. 
After the prerequisite test is carried out, the t-test analysis is used to analyze the learning results of the experimental class and control class students which are analyzed based on the students' final test scores, as shown in Table 3.

Table 3.Test Differences in Learning Outcomes (t-test)

\begin{tabular}{cccc}
\hline \multicolumn{2}{c}{ t-test Value } & $\begin{array}{c}\text { Comparison of t-test values } \mathbf{t}_{\text {table }} \\
\leq \mathbf{t}_{\text {count }} \leq+\mathbf{t}_{\text {table }}\end{array}$ & Conclusion \\
\hline $\mathbf{t}_{\text {count }}$ & $\mathbf{t}_{\text {table }}$ & & $\mathrm{H}_{\mathrm{o}}$ rejected $\left(\right.$ accepted $\left.\mathrm{H}_{\mathrm{a}}\right)$ \\
\hline 7,84 & 2,02 & $2,02 \leq 7,84 \geq+2,02$ & \\
\hline
\end{tabular}

Based on the results of the analysis with a df of 42 , the $t_{\text {table }}$ value at a significant level of $5 \%$ $=2.021$ is obtained. While the value of $t_{\text {count }}=7.84$. Thus, $H_{a}$ is accepted and $H_{o}$ is rejected, which means that the two variables have differences. The conclusion that can be stated is the difference in student learning outcomes with high initial mathematical abilities with low mathematical abilities on probability learning outcomes. These results have actually shown that learning with early mathematical skills gives a better low mathematics which gets as shown in Table 4 .

Table 4. Correlation Test (test phi $(\Phi)$

\begin{tabular}{|c|c|c|c|}
\hline \multicolumn{2}{|c|}{ Nilai Uji $\Phi$} & Comparison & \multirow{2}{*}{ Conclusion } \\
\hline$r_{\text {count }}$ & $r_{\text {tabel }}$ & $r_{\text {tabel }} \leq r_{\text {count }}$ & \\
\hline 0,873 & 0,305 & $0,305 \leq 0,873$ & $\mathrm{H}_{\mathrm{o}}$ rejected (accepted $\left.\mathrm{H}_{\mathrm{a}}\right)$ \\
\hline
\end{tabular}

Based on the results of the calculation analysis, the value of the assessment of phi $=0.873$ is greater than the label obtained at the significance level of 0.05 or $5 \%$, which is equal to 0.305 . Then $r_{\text {tabel }} \leq r_{\text {count }}$ or $0.305 \leq 0.873$. Thus, students' initial mathematical skills have a significant impact in influencing student learning outcomes on probability material.

This study aims to find out how the influence of initial mathematical knowledge results on student learning outcomes in the subject of probability, and more deeply to see how the significant influence of initial mathematical knowledge affects student learning outcomes. The implementation of social industry 5.0 emphasizes the learning process that has high characteristics and good culture, in other words, lecturers are required to be able to provide information to students in a more interesting way so that students can be more enthusiastic in the lecture process (Sarsengeldin, Satabaldiyev, Meirambek, \& Guvercin, 2013; Sumirattana, Makanong, \& Thipkong, 2017). Lecturers who are required to be able to master one of the creative technologies in the digital world are the media, which must be required to build students' critical thinking skills (Hadar \& Tirosh, 2019; Legesse, Luneta, \& Ejigu, 2020; Nasri et al., 2010). This is because not all students have high critical thinking skills and emerge from themselves in the recovery process; in other words, no student curiosity arises in him to carry out lecture activities.

In the lecture process, work from within and from outside the student is needed, which is commonly referred to as student confidence (Sulman, 2019). This is because students' initial 
mathematical abilities in learning can encourage people to achieve maximum learning outcomes, motivation can facilitate the means within students to analyze and know something new that is being analyzed or formulated, and it is important to be observed, observed, and applied ability (Miller, Deci, \& Ryan, 1988). Early mathematics can be at the forefront of individual students to create a better life, (Nasri et al., 2010), and no less important, students' mathematical abilities can make it easier and encourage student interest as well as play an important role in carrying out the lecture process, students who have a high interest will increasingly tend to get more lecture material that conveys better mathematical understanding in the learning process so that students can be better, one of which is early mathematical ability. Early mathematical abilities that can be a basis and solution to improve student learning outcomes to be more perfect, and can make students motivated themselves as physicists on probability lecture material, (Yotongyos et al., 2015) Students will become increasingly interested and enthusiastic about the material being studied so that learning outcomes will be maximized and lecture objectives can be achieved easily.

Based on the findings of researchers in the field, both in the form of data on the results that have been analyzed, it can be drawn from the conclusion that there are differences in the improvement of learning outcomes in both the experimental class and the control class in the study. Researchers try not to provide a difference in the learning process in this study, it is found that it is only before lectures begin, namely the initial mathematical ability, this makes students interested so that their interest in themselves is to understand the material being studied.

Learning by using initial mathematical abilities in the probability material in the experimental class and control class, are both seen with the initial mathematical abilities of students, it can be concluded that the differences given are only for the initial mathematical abilities, but the effect is only on the initial mathematical abilities, but the effect is different for the initial mathematical ability, but the effect is completely different.

Students will get a feeling to be more interested in understanding probability material and increase their curiosity about the material being presented. (Kusmanto \& Marliyana, 2014) The difference is very clear when children have low mathematical connections, there are times when students are bored to get the material because it is felt that there are many in the offline media, deficiencies that cause students to not be interested in expressing their opinions and some are afraid to answer because they feel wrong answering questions will reduce orders, in other words knowledge based on needs and desires but based more on material that must be based on needs (Amalia, 2017) Whereas in the initial mathematical abilities of students who dare to express their understanding of the material being studied (Sulman, 2019) and students who dare to be more in the material of probability studied and when discussing further probability material analysis they are open in conveying good understandings that they do not understand, and in terms of the purpose 
of carrying out the courses compiled can be achieved well and the level of student satisfaction with the material provided is very good.

The difference in learning outcomes that occurs in the control class is due to the low initial mathematical ability (Legesse et al., 2020). The presentation of the material cannot be channeled properly. Students tend to find it difficult to understand the material they are analyzing, even though only a few of them have the initial mathematical ability to analyze more deeply in probability, under certain conditions the spirit of student analysis cannot be raised during the lecture process, the tendency of students' difficulties regarding the importance of the probability material so occurs prostate for students to be able to explore the material presented. Students tend to accept lecturers and feel the material used cannot be implemented. In the control class, when the average initial mathematical ability of students is low, in the implementation of lectures some materials are delivered that almost do not affect students' curiosity. Loading the initial mathematical ability of students is the best option in improving the quality of recovery in probability material. However in this study only looked at students' initial mathematical abilities without seeing other variables that could affect student learning outcomes. It is suggested to the next researcher to be able to review other aspects that might affect students' abilities, for example, gender, student economy, and student beliefs before lectures are held.

\section{CONCLUSION}

Evaluation of the learning process of cognitive students with the initial mathematical ability of semester VI students where the experiment class is higher than the student's learning results in the cognitive realm in the control class. This can be seen from the analysis of the learning cognitive aspects outcomes test in the experimental class with an average value of 87.30. Meanwhile, cognitive learning outcomes in the control class with an average value of 73.70. And after doing the "t" test shows that $\mathrm{t}_{\text {count }}>\mathrm{t}_{\mathrm{table}}$ or $7.84>2.02$. In other words, the resulting difference is that the experimental class is better than the control class.

The magnitude of the significance of the initial mathematical ability in the cognitive domain in the 6th semester, where the experimental class proved to have a significant effect after the analysis conducted the phi correlation test. Based on the calculation of the correlation test phi $(\Phi)$ with a significance level of $5 \%$ is $r_{\text {count }}>r_{\text {table }}$ or $0.873>0.305$. Thus that the initial mathematical ability affects the learning outcomes of the probability material where the effect is given which is significant.

\section{REFERENCES}

Amalia, R. (2017). Kemampuan Berpikir Matematis Mahasiswa dalam Menyelesaikan Masalah Geometri. EDU-MAT: Jurnal Pendidikan Matematika, 4(2). https://doi.org/10.20527/edumat.v4i2.2568

Anggralia, R., Deswita, R., Erita, S., Habibi, M., \& Putra, A. (2019). Effect of Model-Eliciting Activities (MEAs) Approach on Students' Mathematical Communication Skills. Edumatica: Jurnal Pendidikan 
EDUMATIKA: Jurnal Riset Pendidikan Matematika

e-ISSN 2620-8911

Volume 3, Nomor 2, November 2020

p-ISSN 2620-8903

Matematika. https://doi.org/10.22437/edumatica.v9i02.7534

Astawa, I. N. T. (2016). Teori - Teori Dalam Dunia Pendidikan Modern. Jurnal Penjaminan Mutu, 1(1), 67. https://doi.org/10.25078/jpm.v1i1.40

Burbules, N. C., Fan, G., \& Repp, P. (2020). Five trends of education and technology in a sustainable future. Geography and Sustainability, 1(2), 93-97. https://doi.org/10.1016/j.geosus.2020.05.001

Fajri, M. (2017). Kemampuan berpikir matematis dalam konteks pembelajaran abad 21 di sekolah dasar. Lemma, 3(2), 1-11.

Gucyeter, S., \& Erdogan, S. C. (2020). Creative children in a robust learning environment: Perceptions of special education teacher candidates. Thinking Skills and Creativity, 37, 100675. https://doi.org/10.1016/j.tsc.2020.100675

Hadar, L. L., \& Tirosh, M. (2019). Creative thinking in mathematics curriculum: An analytic framework. Thinking Skills and Creativity, 33, 100585. https://doi.org/10.1016/j.tsc.2019.100585

Hardiyati, R. (2014). Pengaruh Pendekatan Realistic Mathematics Education Terhadap Kemampuan Berpikir Kreatif Siswa. 3, 1-168.

Hendriana, H., Rohaeti, E. E., \& Sumarmo, U. (2017). Hard Skills dan Soft Skills Matematik Siswa. Bandung: PT Refika Aditama.

Kusmanto, H., \& Marliyana, I. (2014). Pengaruh Pemahaman Matematika Terhadap Kemampuan Koneksi Matematika Siswa Kelas Vii Semester Genap Smp Negeri 2 Kasokandel Kabupaten Majalengka. Eduma : Mathematics Education Learning and Teaching, 3(2). https://doi.org/10.24235/eduma.v3i2.56

Legesse, M., Luneta, K., \& Ejigu, T. (2020). Analyzing the effects of mathematical discourse-based instruction on eleventh-grade students' procedural and conceptual understanding of probability and statistics. Studies in Educational Evaluation, 67, 100918. https://doi.org/10.1016/j.stueduc.2020.100918

Marsitin, R., \& Sesanti, N. R. (2019). Kemampuan berpikir matematis dalam pembelajaran discovery link map pada integral. Conference on Innovation and Application of Science and Technologi, Ciastech, 135-140. https://doi.org/2622-1284

Maulida, A. R., Suyitno, H., \& Asih, T. S. N. (2019, February). Kemampuan Koneksi Matematis pada Pembelajaran CONINCON (Constructivism, Integratif and Contextual) untuk Mengatasi Kecemasan Siswa. In PRISMA, Prosiding Seminar Nasional Matematika, 2, 724-731.

Miller, K. A., Deci, E. L., \& Ryan, R. M. (1988). Intrinsic Motivation and Self-Determination in Human Behavior. Contemporary Sociology. https://doi.org/10.2307/2070638

Nasri, N. M., Yusof, Z. M., Ramasamy, S., \& Halim, L. (2010). Uncovering problems faced by science teacher. Procedia - Social and Behavioral Sciences, 9, 670-673. https://doi.org/10.1016/j.sbspro.2010.12.215

Nuriana, R. D., \& Yaya, S. K. (2014). Developing Test of High Order Mathematical Thinking Ability in Integral Calculus Subject. International Journal of Education and Research, 2(12), 101-108.

Safi'i, I. (2017). Perancangan Sistem Informasi Jurnal Perkuliahan Sebagai Upaya Monitoring dan Evaluasi Proses Pembelajaran (Studi Kasus : Prodi Teknik Industri Fakultas Teknik Universitas Kadiri). JATI UNIK : Jurnal Ilmiah Teknik Dan Manajemen Industri, 1(1), 1. https://doi.org/10.30737/jatiunik.v1i1.64

Sarsengeldin, M., Satabaldiyev, A., Meirambek, Z., \& Guvercin, S. (2013). Interdisciplinary Connections and their Influence on Mathematical Education of Students. Procedia - Social and Behavioral Sciences, 89, 866-871. https://doi.org/10.1016/j.sbspro.2013.08.946

Sugiyono. (2014). Metode Penelitian Kuntitatif, Kualitatif, dan R\&D. Alfabeta.

Sulman, F. (2019). Application of Cooperative Problem Posing and Prior Motivation Towards Students Learning Outcomes. 4(2), 93-96.

Sumirattana, S., Makanong, A., \& Thipkong, S. (2017). Using realistic mathematics education and the DAPIC problem-solving process to enhance secondary school students' mathematical literacy. Kasetsart Journal of Social Sciences, 38(3), 307-315. https://doi.org/10.1016/j.kjss.2016.06.001

Taqwa, M. R. A., Shodiqin, M. I., \& Zainuddin, A. (2020). Kesulitan Mahasiswa Dalam Memahami Konsep Gaya Dan Gerak. LENSA (Lentera Sains): Jurnal Pendidikan IPA, 10(1), 25-39. https://doi.org/10.24929/lensa.v10i1.86 
EDUMATIKA: Jurnal Riset Pendidikan Matematika

e-ISSN 2620-8911

Volume 3, Nomor 2, November 2020

p-ISSN 2620-8903

Wahyuni, A., \& Kurniawan, P. (2018). Hubungan Kemampuan Berpikir Kreatif Terhadap Hasil Belajar Mahasiswa. Matematika, 17(2), 1-8. https://doi.org/10.29313/jmtm.v17i2.4114

Widodo, T., \& Kadarwati, S. (2013). To Improve Learning Achievement. Cakrawala Pendidikan, 32(1), 161171.

Yotongyos, M., Traiwichitkhun, D., \& Kaemkate, W. (2015). Undergraduate Students' Statistical Literacy: A Survey Study. Procedia - Social and Behavioral Sciences, 191, 2731-2734. https://doi.org/10.1016/j.sbspro.2015.04.328 